\title{
THE EFFECTS OF E-COMMERCE APPLICATION ON TRAVEL AGENCIES AND EMPLOYEE PERFORMANCE
}

\author{
Cihan Seçilmiş ${ }^{1}$ \\ Burhan Sevim ${ }^{2}$ \\ Barış Yilmaz ${ }^{3}$
}

\begin{abstract}
E-commerce, which has been a very prominent issue with the help of current developments in information and communication technologies and worldwide prevalence of the internet, has been intensively used considering the benefits for both customers and businesses. Tourism businesses, which demand to be successful in such rapidly changing competitive business environments, attempt to develop e-commerce applications in order that they can compete with their competitors and make use of new opportunities. It is emphasized that despite the various benefits of e-commerce, it might also bring the end of some sectors, which have not developed essential arrangements and infrastructures for this virtual environment. It is estimated that the need for package tours, tour operators and travel agencies will decrease in the future depending on the growing interest in the independent travel, the number of searches that people make on the internet search engines and tendency to act in accordance with the travel programs. The primary aim of this study is to figure out how much travel agencies in Eskişehir use the e-commerce, the positive and negative effects of e-commerce on travel agencies and how e-commerce is perceived by agency administrators and employees. Besides, this study aims at determining the relationship among the perceptions of these employees and their performance. Within the scope of this research, 61travel agencies operating in Eskişehir were selected and a survey consisting of close-ended questions applied to these business administrators and employees. The results revealed that almost all travel businesses have a web site, and the most important reason why they use the internet is easy accessibility and getting new customers. Employees think that use of e-commerce will not have any negative effect on the future of their businesses. According to results of correlation analysis, there was significant relationship found between employees' perceptions about the effects of e-commerce use on businesses and their performance in which they are employed.
\end{abstract}

Key words:E-commerce, travel agencies, employee performance

\section{INTRODUCTION}

The great opportunities human have come on the scene by information Technologies and the developments of computer World. Information and communication Technologies have become inseparable part of human by means of mobile phones, identity information, commercial accounting operations, e-commerce, banking operations and Daily routines.

In terms of tourism, the dimensions of the sector have been extending day by day, become widespread and globalize. Parallel all these developments the last stage of information Technologies provide new opportunities and advantages by means of management, marketing, advertising and introducing to the enterprises working on tourism sector. The enterprises working on tourism sector has started to take the benefit of information

\footnotetext{
${ }^{1}$ Associate. Professor, Department of Tourism, Tourism Faculty, University of Eskişehir Osmangazi, Eskişehir, Turkey.

${ }^{2}$ Assistant Professor, Department of Tourism, Faculty of Social Science, International Hodja Ahmet Yesevi Turkish-Kazakh University, Kazakhstan.
} 
Technologies intensively. The intensive internet usage and e-commerce has brought a new dimension to the sector (Bayekeyeva, 2009).

The fast development and becoming widespread of technology and internet caused lots of changes and developments on global commerce. These changes also bring arguments about the advantages and disadvantages of internet. With these argumentsthe limitations of services and outcomes have become the part of the arguments (Sarış1k \& Akova, 2006).

Common internet usage in tourism sector which has a great role in global commerce affects the travel agencies which provide the connection between customers and enterprises directly. Especially on the recent years the developments on e-commerce have make people think of the future of travel agencies and their staff. The thoughts about the ecommerce practices of the staff of A group travel agencies in Eskisehir and how ecommerce effect their performances has been studied on this workout.

\section{E-COMMERCE AND EMPLOYEES PERFORMANCE}

\subsection{E-Commerce Concept}

It is possible to define electronic commerce (e-commerce) as the production advertising, selling and delivering of services and productions on electronic environment and telecommunication network (Turban and King, 2003:3).

By globalizing and technological developments the boundaries between countries have removed, the importance of e-commerce has been increased day by day by means of economy. Even if e- commerce is a new system in economy it is not totally distinguished from traditional commerce and the same and partly similar ways has been used. (Ekici and Y1ldirım, 2010:69). To make e-commerce on internet a supply chain and a distribution channel has to be arranged and managed. It is a must to transport the goods and services to the right place at the right time with e-commerce. (Banger, 2000:46). The characteristics of e-commerce are arranged like this (Taşliyan, 2006:50):

- The services served in e-commerce determine the future of the enterprise.

- E-commerce is the greatest door opens to the World for an enterprise.

- E-commerce is global and needs to be pulled away from regionalism.

- 7 days 24 hours working base puts away the time problem that limits the communication and marketing.

- The trustworthiness of e-commerce would increase by developing technology by time.

- Personal commerce relationship can be done by collecting personal information by the help of e-commerce database.

- E-commerce addresses consumers having a different culture and this culture is becoming wide by growing up the internet.

- Due to the fact that the customer and the dealer make trade by not seeing each other some additional measures has to be taken for mutual trust.

The most e-commerce using countries are in Europe, North America, and Far East Pacific as in World wide. Parallel to the developments in Worldwide there are some important developments on e-commerce also in Turkey. By 1996 internet has started to be used not only in the universities but also by others make to increase internet users. By this 
development the enterprises in our country has started to use e-commerce in enterprise to enterprise and to customers (WTO).

The most e-commerce used areas are: digital electronics, life, automotive, hobby-sports, supermarkets, food, flower, fruit, souvenirs, opportunity sites, organization tickets, travel booking, fashion, beauty, multi category shopping, etc. (Taşlıyan, 2006:66).

\subsection{E-commerce on tourism}

The globalization and technologic applications' contribution is great on serving new and flexible duties and increasing competitive power of tourism enterprises. The great need of getting and emitting information for the potential customers in tourism makes these enterprises one of the most important sectors to use e-commerce tools. Tourism enterprises uses e-commerce tools while communicating, introducing, marketing, advertising and managing(Avc1kurt and Köroğlu, 2004:280).

It is very common to use e-commerce in tourism and it is developing day by day. Producing travel services, advertising, introducing, public relations, buying selling procedures, payment and delivery are all possible by e-commerce in tourism (Altaş, 2010:12).

The advantages of e-commerce in tourism are as; (Akbulut, 2007:9-14):

- The profit increases due to the agencies are disabled.

- The enterprises have the opportunity to increase their service quality by ecommerce.

- The decrease of transaction costs and transportation costs is an advantage for customers.

- The prestige of the enterprises using e-commerce increases against competitors.

- The communication between enterprises and customers increases.

- The enterprises using e-commerce can serve 7/24.

- Enterprises can use human resources more convenient and flexible.

But as it has a lot of advantages it also has disadvantages like in all areas using technological developments. The enterprises that cannot accommodate go into liquidation. The disadvantages of e-commerce in tourism are as; (P1rnar, 2005:18):

- Worry in credit usage,

- Security problems due to e-commerce data base problems,

- To send messages and a mails which are not ethic to everybody,

- Parallel to technological developments, thelegal arrangements are slowly produced so legal gaps occur.

- The personal information is used in internet.

- Worry about Hackers during operations.

- Non-detected shopping enterprise.

\subsection{E-Commerce applications of Travel Agencies and tour Operators}

Tourism an important part of global trade is one of the most widely e-commerce used sectors. On recent years some important developments rise on internet and e-commerce applications on the travel agencies providing the connection between customers and enterprises ( Sarışık ve Akova,2006:1). 
E-trade effects the way of marketing and delivering of the travel agencies own services directly. The e-trade applications was first for only getting information but in recent years it became a work potential power by developing (William, 1999:67-73).

On the other hand some researchers emphasize that, the wide internet usage and directing customers to shop from internet may threat the future of agencies. It is predicted that the role of the agencies in tourism will decrease and this might cause they would be closed or unite with greater agencies (Reinders ve Baker, 2004).

The successful travel agencies using e-trade applications are causing the decrease of traditional delivery channels. Lots of researchers think that information provider agencies would be closed in very near future(Marino, 1999; Maselli, 2002). In addition to that the agencies that have e-trade data bases and use internet effectively would reach broad mass and by this way their profit and market share would increase (Kotler vd., 1999).

\subsection{Performance and Employees Performance}

Performance is a concept that states how a person or a group who does that work hits the target quantitively and qualitatively. Personal or group performance is a measure that how much the target is hit and reached the standards. The primary goal for the enterprises is the personal performance of the employees. As much as the personal performance is better the enterprises performance gets better(Benligiray, 2004:141).

Performance is used as a synonym of productiveness but it is not enough. Productiveness is the level of realization of the product in time and in the cost boundary to hit the target of the enterprise but performance includes activity, quality, the quality of work life aim addition, so productivity can be thought as a measure in performance concept (Kaplan, 2007: 57-58).

\section{RESEARCH}

\subsection{Target of the research}

The aim of this research is to exhibit the e-trade use level of the travel agencies working in Eskisehir and the opportunity and threat e-trade perception of the employees and to investigate if this perception affects their performance.

\subsection{The method of the research}

The universe of this research is the 61 travel agencies located in Eskisehir. The sample has gone all and for the health of the health of the answers 167 answers were taken between April 04, 2015 - April 25, 2015 and 163 was chosen for assessment.

To reach the aim of the research different surveys that has been done by different surveyors at different times at the different universes. At this aim, some questions were taken from the survey produced by Y1ldirım (2014) to measure the attendance levels of the employees of business management about e-trade and from the survey which is done by Bayekeyeva (2009) and a new survey is produced by the researcher. A 4 item server performance scale has been used which is developed by Kirkman and Rosen (1999). 


\subsection{The validity and reliabity of the research}

To provide the reliability of the data Cronbach alpha reliability factor is used.. reliability criteria $(0,60<\alpha<0,80)$ is too much reliable $(0,80 \leq \alpha<1,00)$ is very reliable. The measure of the attendance levels of the employees of business management about e-trade is $\alpha=0,71$, the employees performance reliability criteria is calculated as $\alpha=0,88$. This scale shows us that the research is too much reliable(Yaşar, 2014).

\section{RESEARCH EVIDENCE AND ANALYSIS}

The research evidence is as followed below at first the demographic specialties and the statistical evidences.

\subsection{The evidences of the demographic specialties of the participants}

As it can be seen at the table below the demographic specialties of the example mass can exemplify the group in the total sample.

Tab. 1. The statistic evidence of the demographic specialities of the applicants

\begin{tabular}{|l|l|l|l|l|l|}
\hline Sex & $\mathbf{f}$ & $\mathbf{\%}$ & Tourism & $\mathbf{f}$ & $\mathbf{\%}$ \\
\hline Male & 96 & 58,9 & No & 55 & 33,7 \\
\hline Female & 67 & 41,1 & Yes & 108 & 66,3 \\
\hline Total & 163 & 100,0 & Total & 163 & 100,0 \\
\hline Education & & & Age & $\mathbf{f}$ & $\%$ \\
\hline Prep school & - & - & Lower than 20 & 12 & 7,4 \\
\hline High school & 44 & 27,0 & Between 21 - & & \\
\hline Associate degree & 31 & 19,0 & Between 30 - & 43 & 26,4 \\
\hline University & 79 & 48,4 & Between 40 - & 22 & 13,5 \\
\hline Post graduate & 9 & 5,6 & 50 and more & 2 & 1,2 \\
\hline Total & 163 & 100,0 & Total & 163 & 100,00 \\
\hline Experience & $\mathbf{f}$ & $\mathbf{\%}$ & Title & $\mathbf{f}$ & $\%$ \\
\hline Less than 1 year & 56 & 34,4 & Management & 24 & 14,7 \\
\hline 1-5 year & 79 & 48,5 & Departmental & 33 & 20,2 \\
\hline 6-10 year & 20 & 12,3 & Employee & 98 & 60,1 \\
\hline 11-15 year & 4 & 2,4 & Trainee & 7 & 4.3 \\
\hline 16 years and & 4 & 2,4 & Other & 1 & 0,7 \\
\hline Total & 163 & 100 & Total & 163 & 100 \\
\hline
\end{tabular}

In table 1 the evidences are placed that shows the demographic specialities that 163 travel agencies applied and answered the survey are used. The $\% 58,9$ 'u of the applicants are male, $\% 41,1$ of them are female. The age separation of the applicants are $\% 7,4$ is less than 20 years old, $\% 51,5$ of them are between $21-29, \% 26,4$ of them are between 30-39, \%13,6 of them are between $40-49$ and \%1 of them are more than 50 years old. The education level of the applicants are $\% 27$ high school degree, $\% 19,0$ of them are associate degree, $\% 48,4$ of them are university degree, $\% 5,6$ of them are post graduate degree. There is no primary school degree in the applicants. In addition to that $\% 33,7$ of the applicants have 
never get tourism education $\% 66,3$ of them get the education. The titles of the applicants $\% 14,7$ work as management, 20,2 of them work as department managers, 60,1 work as employee, 4,3 work as trainer and \%1 is the enterprise owner. Also, the experience level of the applicants, \%34,4 work less than 1 year, \%48,5 between 1-5 years , \% 12,3 between 610 years , \%1,9 between $11-15$ years andmore than 16 years.

\subsection{Evidence about the General assessment of the enterprise}

Tab. 2. The general information about the enterprise

\begin{tabular}{|l|l|c|c|}
\hline \multirow{4}{*}{$\begin{array}{l}\text { Does your enterprise have an } \\
\text { internet site? }\end{array}$} & variable & $\mathbf{f}$ & $\mathbf{\%}$ \\
\hline \multirow{4}{*}{$\begin{array}{l}\text { How was your page } \\
\text { produced? }\end{array}$} & No & 163 & 100,0 \\
\cline { 2 - 4 } & $\begin{array}{l}\text { An expert working in the } \\
\text { enterprise. }\end{array}$ & 28 & - \\
\cline { 2 - 4 } & Consultant from another firm. & 55 & 37,2 \\
\hline \multirow{4}{*}{$\begin{array}{l}\text { How often does your site } \\
\text { updated? }\end{array}$} & $\begin{array}{l}\text { It is produced totally by } \\
\text { experts. }\end{array}$ & 80 & 49,1 \\
\cline { 2 - 4 } & Daily & 73 & 44,8 \\
\cline { 2 - 4 } & Weekly & 58 & 35,6 \\
\cline { 2 - 4 } & Yonthly & 27 & 16,6 \\
\hline \multirow{2}{*}{$\begin{array}{l}\text { Does your enterprise e- } \\
\text { commerce? }\end{array}$} & Yes & 65 & 3,0 \\
\hline Total & No & 68,2 \\
\hline
\end{tabular}

All the enterprises that the surveys done have internet sites. The internet sites were produced by $\% 17,2$ by an expert working at the same enterprise, $\% 33,7$ by a counselor from outside, $\% 49,1$ by an expert from outsource. The update period of these sites 44,8 daily, \%35,6 weekly, \%18,4 monthly and \%3,9 yearly. The enterprises in the research $\% 58,2$ make e-trade $\% 41,8$ of them have done never.

\subsection{The evidences about the employees' e-trade perception}

The importance range of the opinions on the advantages of e-trade usage at the enterprises can be seen at table 3. Applicants Show that the importance of e-trade to the enterprise are it provides low cost $(4,38)$ and life is easier and faster $(4,33)$ Other benefits are it provides more holiday choices and effects shopping and marketing positively. The minimal attendance is on the decrease of risks. The correlation test due to applicants performance level, low cost opportunity (r:,188**, p<,05), life is easier and faster $\left(\mathrm{r}:, 206^{* *}, \mathrm{p}<, 05\right)$, effects shopping and marketing positively. (r:,151**, $\mathrm{p}<, 05)$, has meaningful evidences. 
Tab. 3. The advantages that e-trade provides to the enterprise

\begin{tabular}{|c|l|c|c|c|}
\hline & \multicolumn{1}{|c|}{ med } & $\begin{array}{c}\text { std. } \\
\text { Dev.ma }\end{array}$ & Performance \\
\hline 1 & $\begin{array}{l}\text { Serving on internet provides agencies } \\
\text { low cost opportunity. }\end{array}$ & 4.38 & 1.19 &, $188^{* *}$ \\
\hline 2 & Life will be easier and faster by e-trade. & 4.33 & 0.92 &, $206^{* *}$ \\
\hline 3 & $\begin{array}{l}\text { Service on internet provides more } \\
\text { holiday choice opportunities. }\end{array}$ & 4.17 & 0.76 &, 104 \\
\hline 4 & $\begin{array}{l}\text { Service on internet provides selling and } \\
\text { trade positively. }\end{array}$ & 4.11 & 1.04 &, $151^{* *}$ \\
\hline 5 & $\begin{array}{l}\text { Service on internet provides the increase } \\
\text { of service quality of the agencies. }\end{array}$ & 4.01 & 0.58 &, $406^{* *}$ \\
\hline 6 & $\begin{array}{l}\text { By the help of internet personal service } \\
\text { can be done to the customers. }\end{array}$ & 3.94 & 0.17 &, 123 \\
\hline 7 & $\begin{array}{l}\text { Internet is a special area for the agencies } \\
\text { by means of their brand image. }\end{array}$ & 3.88 & 0.88 &, 095 \\
\hline 8 & $\begin{array}{l}\text { Service on internet provides customer } \\
\text { communication quality. }\end{array}$ & 3.75 & 0.71 &, 009 \\
\hline 9 & $\begin{array}{l}\text { Service on internet provides customer } \\
\text { reliability much more easily. }\end{array}$ & 2.65 & 0.24 &, $406^{* *}$ \\
\hline 10 & $\begin{array}{l}\text { Service on internet provides the decrease } \\
\text { of risks. }\end{array}$ & 2.42 & 1.23 &, 062 \\
\hline Note: Assessment has been done by 5Likertmeasure. & & \\
\hline
\end{tabular}

Tab. 4. Harms of e-trade for the enterprises

\begin{tabular}{|l|l|l|l|l|}
\hline & \multicolumn{1}{|c|}{} & med & std. & Per \\
\hline 1 & $\begin{array}{l}\text { Agencies lose their customers because of the technological } \\
\text { unreliableness of e-trade applications. }\end{array}$ & 4.43 & 0.67 & $\begin{array}{l}\text {,- } \\
305 \\
*\end{array}$ \\
\hline 2 & Customer perturbation occurs because of not having one to one & 4.41 & 0.85 &, 111 \\
\hline 3 & Too much updates may cause problems. & 4.12 & 1.03 &, 087 \\
\hline 4 & $\begin{array}{l}\text { If too much advertisement is not done there will not be enough } \\
\text { demand. }\end{array}$ & 4.07 & 0.91 &, 006 \\
\hline 5 & Travel sales from internet may cause the end of the travel & 2.10 & 1.56 &,- \\
\hline Note: Assessment has been done by 5 Likert measure. & & \\
\hline
\end{tabular}

Opinions of the applicants about the harms of e-trade for the enterprises can be seen on table 4 due to the importance. Agencies lose their customers because of the technological unreliableness of e-trade applications. $(4,43)$ Customer perturbation occurs because of not having one to one relationship with the customers $(4,41)$ Travel sales from internet may cause the end of the travel agencies is the lowest opinion. The correlation test which has been done due to the performance level of the applicants shows that customer lose because of the technological unreliableness $\left(\mathrm{r}:,-305^{* *}, \mathrm{p}<, 05\right)$ and Travel sales from internet may 
cause the end of the travel agencies risk is (r:,-106**, $\mathrm{p}<, 05)$, which means meaningful negative relationship.

\section{CONCLUSION}

In this research how the e-trade applications used in the travel agencies located in Eskisehir is being perceived by the employees and the relationship between this perception and the employee's performance is examined. The result due to this research can be summarized as below;

The most important piece of the modern trade e- trade is not been used by nearly half of the agencies in Eskisehir is established. The agencies that all have internet pages have to place their internet pages that they can e-trade to continue their long term business.Agencies should make ready their internet pages tu the experts or firms and they have to update these pages more frequently.

It is an advantage that the agency employees agree on that the internet provides easy Access to the enterprises, serves support to market targets, increase the competition power, fast communication with the customers. The positive manner of the employees to internet, is a useful elementfor the agencies to work on e-trade applications.

When the opinions of the employees about e-trade is asked 'proper cost opportunity is provided by serving on internet' is found the most important specialty of e-trade by the average of $(\mathrm{x}=4,38)$ and following this, 'life will be easier and faster by e-trade by the average of $(x=4,33)$ The least importantspecialty is 'serving on internet will lower the risk that has been perceived by customers by the average of $(x=2,42)$ This result shows that the employees of the travel agencies think that e trade will provide low cost, speed and competence but on the other hand, they worry about the unreliableness of the applications working on internet will not cover the customer expectations. This result is parallel to the research result of Semiz (2009).

When it is asked to the applicants for their opinions about the harms of e-trade the most harmful specialty of e trade is chosen as by the average of $(x=4,43)$ "Agencies lose their customers because of the technological unreliableness of e-trade applications' and by the average of $(x=4,41)$ "Customer perturbation occurs because of not having one to one relationship with the customers.' The least averagespecialty is by the average of $(x=2,42)$ "Travel sales from internet may cause the end of the travel agencies.' This result shows us that the agencies employees believe that the customers shop on internet do not trust the technology at all and also the agencies that move all their work on internet will probably lose their customers. The employees believe that customers would like to come to the agency by their own and also want to communicate by real people. On the other hand, agency employees do not find e-trade as a threat that makes their enterprises end. The reason of that is the agencies believe in the musts of this age and keep up with changes and also it can be the trust problem of their customers feel during travel shopping on internet and if there is any problem, the fear of not to find the solution on internet.

Meaningful diversity is been found when the relationship between the opinions of employees and their performances. The employee'sperformance who believes in e-trade will provide lower cost for the agencies, fast and easy business, positive effect on shopping and marketing may increase is emerged. Especially the business which is been done on the internet fast and low cost may increase the employees performances. Besides, the performances of the employees effects negatively by the risks of technology unreliableness of the customers and no need to agencies due to booking on the internet by this no need to 
the agencies and also affect their performances. It is also an argument in the literature that there will be no need to the agencies in future because of the direct booking opportunity on the internet. But it is thought by the employees that a kind of risk will not be seen in short term because some hesitations on e-trade are not been removed yet.

The most important narrowness of this research is it is done only in Eskisehir area but not generalize the assessment for all of the agencies. The latter researches should be done at different areas and it will be useful if the sample should be increased.

\section{REFERENCE}

1. Akbulut, A. (2007). Information Economy and E-Commerce. İstanbul: Yapım.

2. Altaş, A. (2010). Electronic Commerce. İstanbul: Media.

3. Avcıkurt, C., Köroğlu, A. (2013 Şubat). Konaklama işletmelerinin pazarlanmasında internetin kullanımına yönelik bir model önerisi. 9. Mehmet Kemal DEDEMAN Araştırma ve Geliştirme Proje Yarışması, Balıkesir.

4. Banger, G. (2000). Eskişehir Ticaretinde Değişimin önündeki engellierin kısa tahlili ETO Dergisi 17, 78 p. 45-47.

5. Bayekeyeva, G. (2009). E-commerce in tourism sector in Kazakhstan: Practice on hotels and travel agencies. 9 Eylül University Institute of Social Sciences Department of Tourism Management Tourism Management Program, Master's Thesis, Ankara.

6. Benligiray S. (2004). Human Resources Management.Eskişehir, Anadolu Üniversitesi.

7. Ekici, M., \&Yıldırım A. (2010). E-Commerce. Ankara: Savaş.

8. KAPLAN Mehmet (2007) Motivation theories under the application of special program and equipments to measure performance of employer and a case study, At1lım University Institute of Social Sciences, Master's Thesis, Ankara.

9. Kirkman, B. L. ve Rosen B. (1999). Beyond SelfManagement: Antecedents and Consequences of Team Empowerment, Academy of Management Journal, 42(1): 5874.

10. Kotler, P., Bowen, J. ve Markens, J. (1999), Marketing for Hospitality and Tourism, 2nd Edition. Prentice Hall, Upper Saddle River, NJ.

11. Marino, D. (1999). Internet experts urge development of e-commerce models. ASTA AgencyManagement, 68(1), 32-34.

12. Maselli, J. (2002). E-ticketing threatens travel agents. Information Week, 881, 28-29.

13. Özbay, A., Devrim, J. (2000). "E-Commerce Guides" .İstanbul.

14. Pirnar, İ. (2005). E-Trade In Tourısm Industry. Journal of Economic and Social Research, 1(1), 28-55.

15. Reinders, J. ve Baker, M. (1997), “The Future for Direct Retailing of Travel and Tourism Products: The Influence of Information Technology", Proceedings of The International Conference on Information and Communication Technologies in Tourism, Edinburgh, Scotland, 119-127.

16. Sarışık, M.,Akova, O. (2006). Seyahat Acentalarında İnternetin Rolü ve Önemi. Kocaeli Üniversitesi Sosyal Bilimler Enstitüsü Dergisi , 12/2 p.128-148.

17. Semiz, D. , Semiz, H. and Türkoğlu, S. (2009), "E-Ticaretin Hizmet Sektörüne Yansıması Turizm ve Seyahat Acenteleri Üzerine Bir Alan Araştırması”, 14. Türkiye'de İnternet Konferansı (inettr.org.tr/inetconf14/kitap/semiz_semiz_inet09.pdf) Erişim: 11.05.2015 
18. Taşliyan, M. (2006). Elektronik Ticaret, Kavramlar ve Uygulamalar, Kahramanmaras: Sakarya Kitabevi.

19. Turban, E., King D. (2003). Introduction to E-Commerce, Prentice Hall.

20. Turdaliev, C. (2009). Electronic marketing in hotel enterprises: an empirical study at four and five stars hotels in İzmir. 9 Eylül University Institute of Social Sciences, Master's Thesis, İzmir

21. William, H.S. (1999). “Are You Ready for The New Service User?”, Journal ofHospitality and Leisure Marking, 6, p.67-73.

22. WTO (2001), E-Business for Tourism: Practical Guidelines for Tourism Destinations and Business. Madrid: WTO.

23. Yaşar, M. (2014) Attitudes Toward Statistics Scale: Validity and Reliability Study,Journal of Pamukkale University Education Faculty, Sayı 36 (Temmuz 2014/II), p.59-75.

24. Yildırım, H.Y.(2014) E-Commerce In The Tourısm Sector: An Implementation Related To Accomodation Enterprises In Ankara. Gazi University Graduate School Of Educational Sciences Department Of Foreign Trade Master's Thesis, Ankara. 